\title{
Seed Potato Production Practices and Quality of Farm Saved Seed Potato in Kiambu and Nyandarua Counties in Kenya
}

\author{
Bornventure I. Mumia ${ }^{1, *}$, James W. Muthomi ${ }^{1}$, Rama D. Narla ${ }^{1}$, Moses W. Nyongesa ${ }^{2}$, Florence M. Olubayo ${ }^{1}$ \\ ${ }^{1}$ Department of Plant Science and Crop Protection, University of Nairobi, P. O. BOX 30197, 0100 GPO, Nairobi, Kenya \\ ${ }^{2}$ Horticulture Research Institute, National Potato Research Centre (Tigoni), Kenya Agricultural and Livestock Research Organization \\ (KALRO), P.O.BOX 338-0217 Limuru, Kenya \\ *Corresponding author: mechaisaya@gmail.com
}

\begin{abstract}
Potato production in Kenya is mainly constrained by limited supply of quality seed potato tubers. The objective of this study was to determine seed potato handling practices and quality of farm saved seed potato. A survey involving 79 farmers was conducted in potato production areas in Kiambu and Nyandarua Counties to collect information on seed potato production practices including sources of seed tubers, seed selection, seed tuber storage, pests and diseases. Samples of seed potato were collected from farmers and evaluated for quality parameters such as tuber size, weight, stout sprout length and infection with diseases. Factors affecting potato production included limited quality seed supply, pests and diseases. Shangi was the main potato variety grown by majority (62.8\%) of farmers and all the farmers used own farm saved seed. Most (45.5\%) farmers recycled the seed for four seasons and $44.1 \%$ of farmers stored seed potato for three months. Freeness from seedborne diseases was the main seed quality preference by farmers. The main pest reported was cutworms ( $42.6 \%$ of farmers) while potato late blight and bacterial wilt were the major diseases reported by $87.1 \%$ and $86.7 \%$ of the farmers respectively. All farm saved seed potato samples were infected with Fusarium coeruleum, 51.2\% with Rhizoctonia solani, 53.3\% with Fusarium sambunicum, 33.3\% with Fusarium solani and $48.3 \%$ with Aspergillus niger. Over $69 \%$ of the farm saved seed samples were infected with Ralstonia solanacearum while $40.1 \%$ were infected with Potato Virus S, the most dominant. Due to poor post-harvest handling practices, farmers incurred seed quality and quantity losses in storage. Farm saved seed is contaminated with multiple seed borne diseases. Farmers should be sensitized on appropriate seed potato handling practices and there should be increased supply of certified seed potato.
\end{abstract}

Keywords: Seed quality, seed borne diseases, seed supply, Solanum tuberosum L.

Cite This Article: Bornventure I. Mumia, James W. Muthomi, Rama D. Narla, Moses W. Nyongesa, and Florence M. Olubayo, "Seed Potato Production Practices and Quality of Farm Saved Seed Potato in Kiambu and Nyandarua Counties in Kenya." World Journal of Agricultural Research, vol. 6, no. 1 (2018): 20-30. doi: 10.12691/wjar-6-1-5.

\section{Introduction}

Potato is the second most important food crop in Kenya after maize and has been used to address food security challenges with declining yield in cereals [1,2]. Due to limited supply of certified seed potato, the main challenge facing potato production in Kenya is use of poor quality seed potato tubers that are highly contaminated with seed borne diseases [3,4]. The informal seed potato supply system made up of farm saved, seed exchanges by farmers and local markets is the main channel of acquiring seed potato tubers in developing countries and it accounts for over95\% of seed potato volumes used $[5,6,7,8]$. Studies in Kenya and Uganda have shown that over $70 \%$ of farmers practice variety and seed selection at farm level in potato production [9]. In Kenya, over 95\% of potato farmers use farm saved seed tubers which are of poor quality especially with accumulation of tuber borne diseases [5,7]. Seedborne diseases such as bacterial wilt (Ralstonia solanacearum), late blight of potato (Phytopthora infestans), dry rot (Fusarium spp.) and potato viruses are carried across cropping seasons leading to an overall decline in seed quality and causing high yield losses [10,11,12].

The main intervention mechanism to averting yield losses is promotion of the use of quality seed potato that is disease free but lack of adequate supply of certified seed potato is a major constraint to farmers $[3,6,13]$. Therefore, most farmers do not use certified seed due to limited supply, high prices and lack of knowledge on its importance $[3,9]$. There is no quality control in seed potato production from informal seed systems and the tubers are of low phytosanitary status $[14,15]$. Seed potato quality attributes include seed health, physical and genetic purity, seed tuber size and the physiological age of tubers [6]. These attributes are met through seed certification in formal seed production unlike the informal seed system where there is no quality control [14]. Seed health is the 
most important attribute since seed borne diseases cause the highest losses $[4,16,17]$. Due to limited supply of certified seed, most farmers recycle seed tubers for many seasons causing an overall decline in seed quality due to accumulation of seed borne diseases such as potato viruses through seed degeneration [11].

Quality attributes used in seed selection include yielding ability, genetic purity, disease resistance, days to maturity, marketability, and size of tubers [6,9]. Lack of adequate knowledge on recommended potato production practices is a major problem facing farmers [18,19]. To mitigate the problems associated with limited supply of certified seed potato, positive selection technique was developed to enhance production of quality seed at the farm level but few farmers have adopted this technology $[18,20]$. Farmers' knowledge on potato diseases, pests and their management is important in potato production [19]. Information flow in potato production affects choices on seed acquisition and production practices. Information sources such as neighbours, markets, Non-Governmental Organizations (NGOs), extension officers and researchers on seed sources and production practices influences the yield obtained by farmers [5,6]. In addition, sources of seed potato, production and post-harvest handling practices affects quality of seed tubers [21].

This study therefore aimed at determining seed potato production practices and quality of farm saved seed potato among small scale farmers in Kiambu and Nyandarua Counties in Kenya.

\section{Materials and Methods}

\subsection{Determination of Seed Potato Production and Handling Practices}

This study was conducted in four Agro-Ecological Zones (AEZs) in Kiambu and Nyandarua Counties in Kenya. The AEZs in Kiambu County were Lower Highland Zone II (LH2) and Upper Midland Zone I (UMI). In Nyandarua County, the AEZs were Upper Highland Zone II (UH2) and Upper Highland Zone III (UH3) [22]. A survey involving 79 farmers was conducted using a questionnaire and the sample size was determined using the formula shown below:

$$
n=\frac{N}{1+N(e) 2}
$$

Where $\mathrm{n}$ is the sample size, $\mathrm{N}$ is the population size. The assumptions of using the formula; There is $95 \%$ confidence level, $\mathrm{P}=0.5$ and error limit $(\mathrm{e})=0.1$ [23].

Information collected included duration of potato production, varieties grown, sources of seed potato, quality traits used in seed selection, duration before seed renewal, methods of seed storage, pests and diseases. Farmers were interviewed in potato growing groups where 15 farmers were interviewed in LH2, 16 in UM1, 25 in UH2 and 23 in UH3. Two kilograms of farm saved seed tubers were obtained from each farmer and taken for seed quality analysis at the Faculty of Agriculture, University of Nairobi.

\subsection{Determination of Physical and Physiological Quality}

Determination of physical quality involved measurement of seed tuber size and tuber weight while physiological quality involved determination of number of sprouts and sprout length following the United Nations Economic Commission for Europe (UNECE) and Food Agriculture Organization (FAO) standards on Quality Control in Seed Potatoes $[24,25]$. Seed potato tubers sizes were graded on basis of four diameter scales namely chatts $(<20 \mathrm{~mm}$ diameter), small (20mm-25mm), medium (25-35mm) and large $(30-35 \mathrm{~mm})$. The weight of individual tubers regardless of the size was taken using a digital balance. Sprouted and unsprouted eyes per tuber were also counted regardless of size. Length of stout sprouts per tuber was measured using a string and a ruler. Data was collected on the number of tubers in various sizes, weight of individual tubers, sprouted eyes and stout sprout length.

\subsection{Determination of Tuber-borne Infection}

Fungal, bacterial and viral diseases were detected in determination of seed borne diseases in farm seed tubers. Detection of dry rot (Fusarium spp.) and black scurf (Rhizoctonia solani) was done using methods described by [26] and [27] respectively. Three seed tubers per sample were randomly drawn and washed under running tap water. Three slices each $6 \mathrm{~mm}$ by $5 \mathrm{~mm}$ were excised from each tuber using a sterilized scalpel. The slices were sterilized in $1 \% \mathrm{NaOCl}$ solution for three minutes and rinsed in three changes of distilled water. The slices were plated on molten Potato Dextrose Agar (PDA) medium at equidistant positions and incubated for seven days at room temperature $\left(23 \pm 2^{\circ} \mathrm{C}\right)$. Resultant colonies were sub cultured on PDA and pure cultures identified using colony morphological characteristics under light microscope. Data was collected on the number of infected slices with fungal pathogens and the individual fungal colony types.

An Enzyme Linked Immunosorbent Assay on Nitrocellulose Membrane (NCM-ELISA) method described by [28] using a kit sourced from International Potato Center (CIP), Lima Peru was used to detect bacterial wilt (Ralstonia solanacearum) in farm saved seed tubers. Three tubers from each replicate of each sample were tested. The tubers were washed in tap water and dipped in $1 \% \mathrm{NaOCl}$ for one minute. The stolon end of each tuber was cut transversally, vascular ring scooped out and crushed in a crushing buffer. The extract was enriched overnight by adding $500 \mu \mathrm{l}$ of enrichment broth. The extracts were loaded alongside positive and negative controls on nitrocellulose membranes soaked in a buffer solution and allowed to dry. Blocking solution was added and allowed to react for an hour with continuous agitation. Binding of $R$. solanacearum antibodies were done by soaking the membranes in an antibody solution for two hours with continuous agitation. Membranes were soaked in a solution with conjugated antibodies for an hour and washed three times using a washing buffer. Colour development was done by adding colour development solution and reaction allowed to run for 30 minutes with formation of purple colour in samples similar to the 
positive controls. Data was collected on samples testing positive for the disease as outlined in the kit [28].

Detection of potato viruses was done using Double Antibody Sandwich Enzyme Linked Immunosorbent Assay (DAS-ELISA) according to $[29,30]$. The DAS ELISA kit was also sourced from CIP, Peru and can detect six potato viruses namely Potato Leaf Roll Virus (PLRV), Potato Virus A (PVA), Potato Virus M (PVM), Potato Virus S (PVS), Potato Virus X (PVX) and Potato Virus Y (PVY). The tubers were allowed to sprout before detection for virus infection. For each virus, $20 \mu \mathrm{l}$ of antibody were dissolved in $20 \mu \mathrm{l}$ of coating buffer, loaded on microtiter plates and incubated for four hours. The leaf and sprout samples were crushed in a crushing buffer and the extract loaded on washed coated plates. Three healthy controls specific to each virus were filled in the last three wells of each plate and loaded plates were incubated overnight. Plates were washed thrice in a washing buffer and conjugate solution added followed by incubation for five hours. Washing was done thrice and substrate solution added until development of yellow colour with healthy controls remaining clear. The number of samples positive for viruses was determined using the concentration of the virus titre calculated using the formula:

$$
x \geq \bar{x} h \times 2
$$

Where $x$ is threshold value of the samples and $\bar{x} h$ is the average values of healthy controls [30].

\subsection{Statistical Data Analysis}

The survey data was analyzed using IBM SPSS $($ statistical software version 20. Bacterial wilt infection and viruses were interpreted by comparing the samples with the positive controls as outlined in the kits. Percentage disease infection after ELISA tests, seed tuber weight and sprouting subjected to analysis of variance using GENSTATC statistical package. Mean separation done using Fisher's protected Least Significant Difference at 5\% level of significance [31].

\section{Results}

\subsection{Seed Potato Production and Handling Practices}

Most (58.5\%) famers grew potato for over five years, only $2.5 \%$ grew for one and two years and none grew the crop for just one season (Table 1). Shangi (62.8\%) was the main variety grown by $62.8 \%$ of farmers compared to Kenya Karibu and Dutch Robjin which was the least grown (Table 2).

Table 1. Percentage of farmers who produced potato over varying number of seasons in different agro-ecological zones in Kikuyu and Nyandarua Counties

\begin{tabular}{|c|c|c|c|c|c|}
\hline \multirow{2}{*}{$\begin{array}{l}\mathrm{N}=79: \\
\text { Duration }\end{array}$} & \multicolumn{2}{|c|}{ Kikuyu $(n=31)$} & \multicolumn{2}{|c|}{ Nyandarua(n =48) } & \multirow[t]{2}{*}{ Mean } \\
\hline & LH2 & UM1 & UH2 & UH3 & \\
\hline 1 Season & 0.0 & 0.0 & 0.0 & 0.0 & 0.0 \\
\hline 1 Year & 0.0 & 6.3 & 4.0 & 0.0 & 2.5 \\
\hline 2 Years & 0.0 & 6.3 & 4.0 & 0.0 & 2.5 \\
\hline $3-5$ years & 6.7 & 12.5 & 20.0 & 47.8 & 17.4 \\
\hline$>5$ years & 93.3 & 75.0 & 72.0 & 52.2 & 58.5 \\
\hline
\end{tabular}

$\mathrm{N}=$ Population, $\mathrm{n}=$ Sample size, LH2=Lower Highland Zone II, UM1=Upper Midland Zone I, UH2=Upper Highland Zone II,UH3=Upper Highland Zone III

Table 2. Percentage of farmers who grew various potato varieties in different agro-ecological zones in Kikuyu and Nyandarua Counties

\begin{tabular}{lrrrrrr}
\hline \multirow{2}{*}{ Varieties } & \multicolumn{2}{c}{ Kikuyu $(\mathrm{n}=31)$} & & \multicolumn{2}{c}{ Nyandarua(n= 48) } & \multirow{2}{*}{ Mean } \\
\cline { 2 - 3 } & LH2 & UM1 & & UH2 & UH3 & \\
\hline Shangi & 12.5 & 46.7 & & 92.3 & 100.0 & 62.8 \\
Tigoni & 37.5 & 20.0 & & 0.0 & 0.0 & 14.3 \\
KenyaMpya & 43.8 & 6.7 & & 0.0 & 0.0 & 12.6 \\
Local & 0.0 & 26.7 & & 0.0 & 0.0 & 6.8 \\
Kenya Baraka & 6.3 & 0.0 & & 0.0 & 0.0 & 1.6 \\
KenyaKaribu & 0.0 & 0.0 & & 3.8 & 0.0 & 1.0 \\
DutchRobjin & 0.0 & 0.0 & & 3.8 & 0.0 & 1.0 \\
\hline
\end{tabular}

$\mathrm{N}=$ Population, $\mathrm{n}=$ Sample size LH2=Lower Highland Zone II, UM1=Upper Midland Zone I, UH2=Upper Highland Zone II, UH3=Upper Highland Zone III

Majority (45.5\%) of the farmers took four seasons to renew seed potato, while $17.2 \%$ and $11.4 \%$ renewed after six and three seasons respectively. Only $1.7 \%$ renewed seed after one season while $16.1 \%$ did not renew seed potato tubers at all (Table 3). Farm saved seed potato was used by all farmers. Local markets (72.8\%), neighbours (31.2\%) and certified seed from research institutions (18.3\%) were other alternative seed sources. Local markets were the second most important seed source and very few farmers used certified seed (Table 4). Freeness from seed borne diseases (69.6\%) was the main seed quality preference, seed tuber size (24.8\%) and sprouting capacity (5.4\%) were the additional seed quality attributes (Figure1). Polythene and jute bags were the main (46\%) methods of seed tuber storage, farm stores (37.7\%), diffused light storage (5.7\%), heaps (4.4\%), dark storage (3.2\%) and field pits (3\%) were also used as methods of storing seed tubers (Table 5).

Table 3. Percentage of farmers who took various seasons to renew seed potato in different agro-ecological zones in Kikuyu and Nyandarua Counties

\begin{tabular}{|c|c|c|c|c|c|}
\hline \multirow{2}{*}{$\begin{array}{l}\mathrm{N}=79 \\
\text { Number of seasons }\end{array}$} & \multicolumn{2}{|c|}{ Kikuyu (n=31) } & \multicolumn{2}{|c|}{ Nyandarua $(n=48)$} & \multirow[t]{2}{*}{ Mean } \\
\hline & LH2 & UM1 & $\mathrm{UH} 2$ & UH3 & \\
\hline 1 & 0.0 & 6.7 & 0.0 & 0.0 & 1.7 \\
\hline 2 & 6.3 & 6.7 & 0.0 & 9.1 & 4.4 \\
\hline 3 & 0.0 & 0.0 & 0.0 & 45.5 & 11.4 \\
\hline 4 & 75.0 & 20.0 & 46.2 & 40.9 & 45.5 \\
\hline 5 & 6.3 & 0.0 & 0.0 & 4.5 & 2.7 \\
\hline 6 & 6.3 & 20.0 & 42.3 & 0.0 & 17.2 \\
\hline No seed renewal & 6.3 & 46.7 & 11.5 & 0.0 & 16.1 \\
\hline
\end{tabular}

N=Population, n= Sample size, LH2=Lower Highland Zone II, UM1=Upper Midland Zone I, UH2=Upper Highland Zone II, UH3=Upper Highland Zone III. 
Table 4. Percentage of farmers who used various sources to acquire seed potato tubers in different agro-ecological zones in Kikuyu and Nyandarua Counties

\begin{tabular}{|c|c|c|c|c|c|}
\hline \multirow{2}{*}{$\begin{array}{l}\mathrm{N}=79 \\
\text { Seed source }\end{array}$} & \multicolumn{2}{|c|}{ Kikuyu (n=31) } & \multicolumn{2}{|c|}{ Nyandarua $(n=48)$} & \multirow[t]{2}{*}{ Mean } \\
\hline & LH2 & UM1 & UH2 & UH3 & \\
\hline Own seed & 100.0 & 100.0 & 100.0 & 100.0 & 100.0 \\
\hline Local market & 70.8 & 72.8 & 64.3 & 83.3 & 72.8 \\
\hline Neighbours & 16.6 & 16.1 & 21.4 & 70.8 & 31.2 \\
\hline Research institutes & 12.5 & 24.3 & 14.3 & 22.3 & 18.3 \\
\hline
\end{tabular}

N=Population, n= Sample size, LH2=Lower Highland Zone II, UM1=Upper Midland Zone I, UH2=Upper Highland Zone II, UH3=Upper Highland Zone III

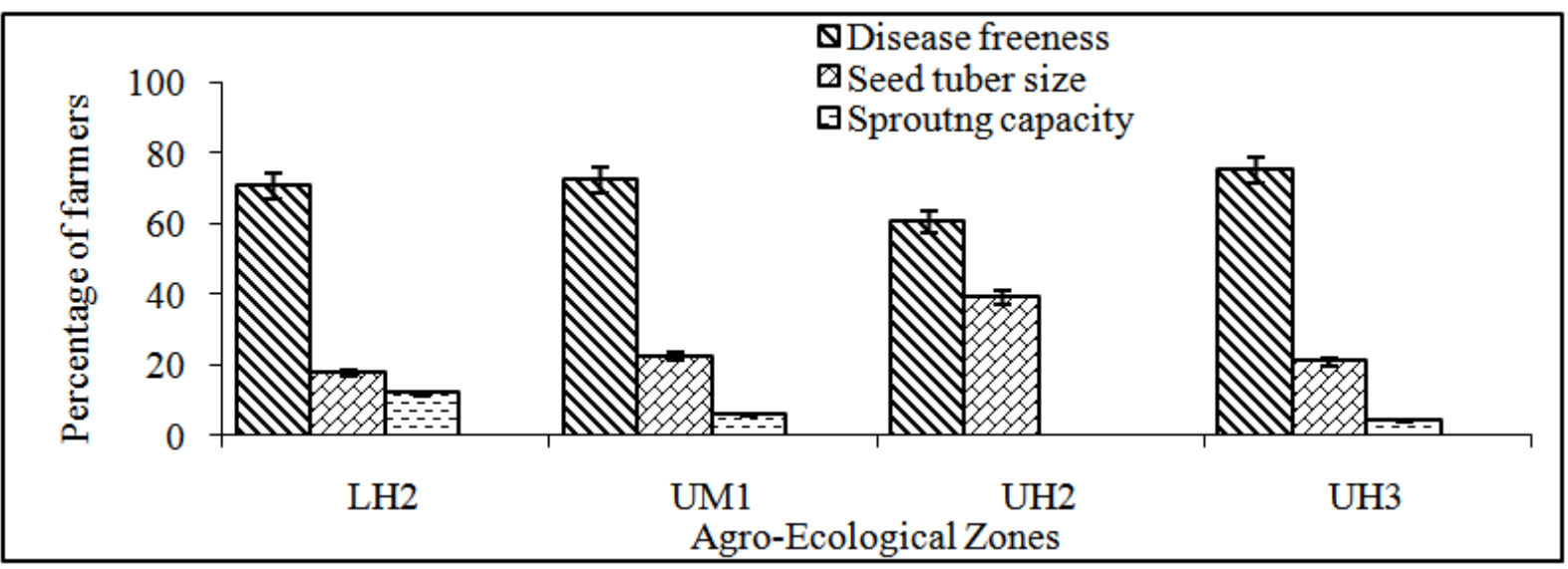

Figure 1. Percentage of farmers who had various seed potato quality preferences in different agro-ecological zones in Kikuyu and Nyandarua Counties

Table 5. Percentage of farmers who used various methods to store seed potato tubers in different agro-ecological zones in Kikuyu and Nyandarua Counties

\begin{tabular}{|c|c|c|c|c|c|}
\hline \multirow{2}{*}{$\begin{array}{l}\mathrm{N}=79 \\
\text { Method of storage }\end{array}$} & \multicolumn{2}{|c|}{ Kikuyu (n=31) } & \multicolumn{2}{|c|}{ Nyandarua(n=48) } & \multirow[t]{2}{*}{ Mean } \\
\hline & UM1 & LH2 & UH2 & UH3 & \\
\hline Heap storage & 6.3 & 6.7 & 0.0 & 4.5 & 4.4 \\
\hline Dark Storage & 6.3 & 6.7 & 0.0 & 0.0 & 3.2 \\
\hline Jute\& polythene bags & 37.5 & 73.3 & 40.9 & 31.8 & 46.0 \\
\hline Farm stores & 37.5 & 13.3 & 54.5 & 45.5 & 37.7 \\
\hline Field pits & 12.5 & 0.0 & 0.0 & 0.0 & 3.0 \\
\hline Diffused light stores & 0.0 & 0.0 & 4.5 & 18.2 & 5.7 \\
\hline
\end{tabular}

N=Population, n= Sample size, LH2=Lower Highland Zone II, UM1=Upper Midland Zone I, UH2=Upper Highland Zone II, UH3=Upper Highland Zone III

Majority (44.1\%) of the farmers stored seed potato for three months but two (33.8\%), four (4.8\%) and one month (4\%) were other storage periods (Table 6). Pests (69.7\%) were the main storage constraint followed by seed tuber rot $(17.8 \%)$, poor sprouting $(12.1 \%)$ and weight loss $(0.45 \%)$. Very few $(0.45 \%)$ farmers reported weight loss as a storage constraint (Table 7). Cutworms (42.6\%) were the major field pest unlike potato tuber moth (38.8\%) the main storage pest. Rodents (20\%) and whiteflies (1.5\%) were also reported (Table 8). Potato late blight (87.1\%) and bacterial wilt (86.7\%) were the major potato diseases faced by farmers in potato production (Figure 2).

Table 6. Percentage of farmers who stored seed potato for various months in different agro-ecological zones in Kikuyu and Nyandarua Counties

\begin{tabular}{|c|c|c|c|c|c|}
\hline \multirow{2}{*}{$\begin{array}{l}\mathrm{N}=79 \\
\text { Storage duration (months) }\end{array}$} & \multicolumn{2}{|c|}{ Kikuyu (n=31) } & \multicolumn{2}{|c|}{ Nyandarua $(\mathrm{n}=48)$} & \multirow[t]{2}{*}{ Mean } \\
\hline & UM1 & LH2 & UH2 & UH3 & \\
\hline 1 & 0.0 & 6.7 & 0.0 & 9.1 & 4.0 \\
\hline 2 & 37.5 & 6.7 & 50.0 & 40.9 & 33.8 \\
\hline 3 & 37.5 & 46.7 & 42.3 & 50.0 & 44.1 \\
\hline 4 & 25.0 & 6.7 & 7.7 & 0.0 & 9.8 \\
\hline
\end{tabular}

N=Population, n= Sample size, LH2=Lower Highland Zone II, UM1=Upper Midland Zone I, UH2=Upper Highland Zone II, UH3=Upper Highland Zone III 
Table 7. Percentage of farmers who used reported various storage constraints during seed potato storage in Kikuyu and Nyandarua Counties

\begin{tabular}{|c|c|c|c|c|c|}
\hline $\mathrm{N}=79$ & \multicolumn{2}{|c|}{ Kikuyu (n=31) } & \multicolumn{2}{|c|}{ Nyandarua $(\mathrm{n}=48)$} & \multirow[t]{2}{*}{ Mean } \\
\hline Constraint & UM1 & LH2 & UH2 & UH3 & \\
\hline Storage pests & 70.6 & 89.9 & 64.3 & 54.0 & 69.7 \\
\hline Seed rot & 10.0 & 11.1 & 21.4 & 29.3 & 17.8 \\
\hline Poor sprouting & 17.6 & 0.0 & 14.2 & 16.7 & 12.1 \\
\hline Weight loss & 1.8 & 0.0 & 0.0 & 0.0 & 0.45 \\
\hline
\end{tabular}

$\mathrm{N}=$ Population, $\mathrm{n}=$ Sample size, N=Sample size, LH2=Lower Highland Zone II, UM1=Upper Midland Zone I, UH2=Upper Highland Zone II, UH3=Upper Highland Zone III

Table 8. Percentage of farmers who reported their potato crop to be affected by field and storage pests in potato production in Kikuyu and Nyandarua Counties

\begin{tabular}{lrrrr}
\hline N=79 & \multicolumn{2}{c}{ Kikuyu (n=31) } & \multicolumn{2}{c}{ Nyandarua (n=48) } \\
\cline { 2 - 5 } Pest & LH2 & UM1 & UH2 & UH3 \\
\hline Cutworm & 23.5 & 46.5 & 46.4 & 54.2 \\
Rodents & 23.6 & 17.8 & 17.8 & 20.8 \\
Tuber moth & 47.1 & 35.7 & 35.5 & 2.6 \\
White flies & 5.9 & 0.0 & 0.0 & 38.0 \\
\hline
\end{tabular}

N=Population, n= Sample size, LH2=Lower Highland Zone II,UM1=Upper Midland Zone I, UH2=Upper Highland Zone 2, UH3=Upper Highland Zone III

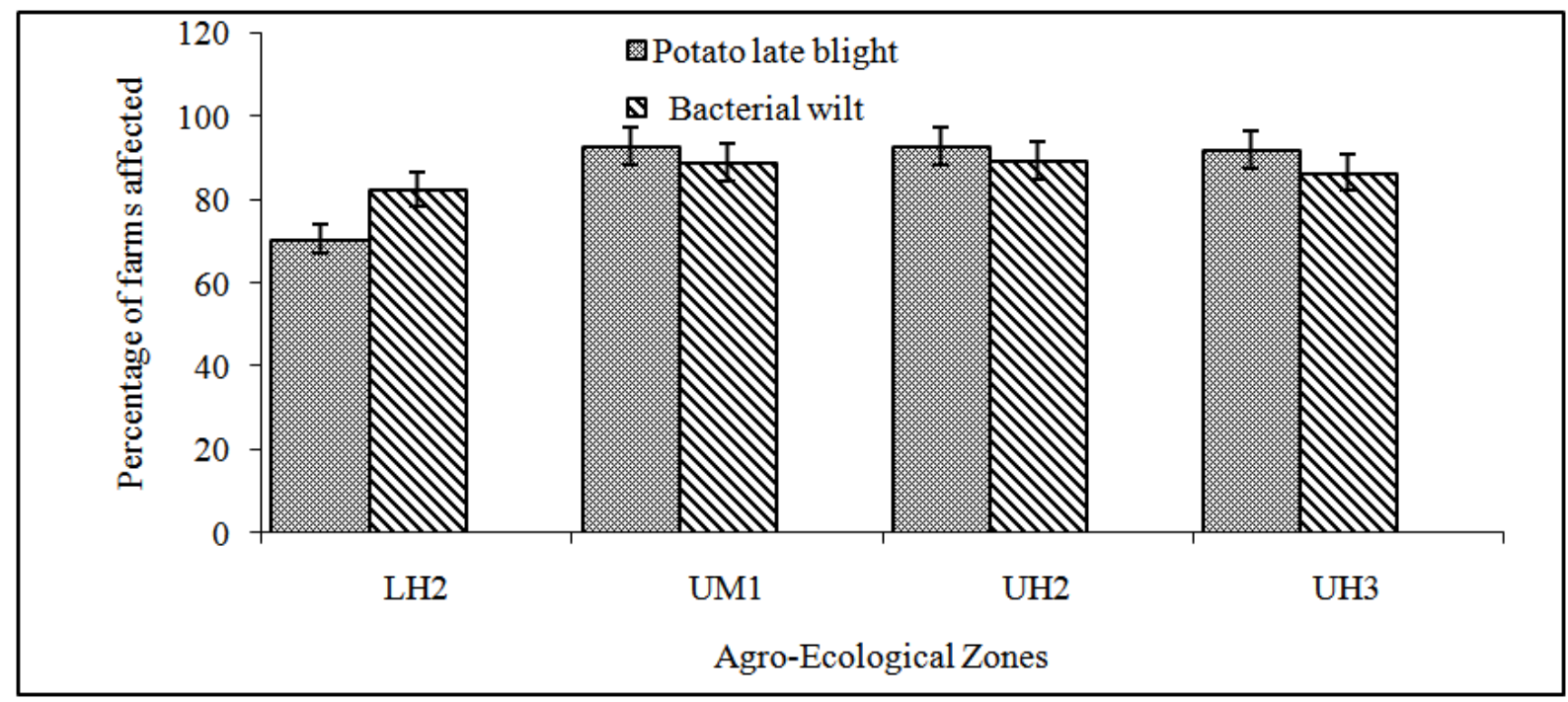

Figure 2. Percentage of farmers who reported their potato crop to be affected by potato late blight and bacterial wilt in different agro-ecological zones in Kikuyu and Nyandarua Counties

\subsection{Physical Quality and Infection with Tuber-Borne Disease Pathogens}

There were no significant differences in small and medium sized tubers used by farmers. However, there were slight variations in medium and large tubers (Table 9). The length of sprouts varied significantly across the sites unlike the weight of seed tubers which were not significantly different at $\mathrm{P} \leq 0.05$ (Table 9). There was up to $87 \% R$. solanacearum infection in farm saved tubers. Despite high $R$. solanacearum infection levels in farm saved seed potato across the four agro-ecological zones, there were no significant differences on disease infection in samples collected from LH2and UM1 unlike significance differences observed in samples collected from UH3 and UH2. Only UH3 had significantly least proportion of samples infected with bacterial wilt with up to $69 \%$ of samples testing positive for the disease. There was higher bacterial wilt infection in Kikuyu (LH2 and UM1) compared to Nyandarua (UH2 and UH3, (Table 9).

Table 9. Sprout length, seed tuber weight, percentage bacterial wilt infection in farm saved seed and grades of tubers used by farmers in different agro-ecological zones in Kikuyu and Nyandarua Counties

\begin{tabular}{|c|c|c|c|c|c|c|c|}
\hline \multirow{2}{*}{$\begin{array}{l}\text { Agro-ecological } \\
\text { zone }\end{array}$} & \multirow{2}{*}{$\begin{array}{c}\text { Sprout } \\
\text { Length }(\mathrm{cm})\end{array}$} & \multirow{2}{*}{$\begin{array}{c}\text { Tuber } \\
\text { Weight(g) }\end{array}$} & \multirow{2}{*}{$\begin{array}{c}\text { Infection } \\
(\%)\end{array}$} & \multicolumn{4}{|c|}{ Weight of tubers by grade } \\
\hline & & & & Chatts & small & Medium & Large \\
\hline LH2 & $1.4 \mathrm{a}$ & $38.6 c$ & $86.6 a$ & $2.5 a$ & $2.8 \mathrm{a}$ & 3.9a & $1.2 \mathrm{ab}$ \\
\hline UH3 & $1.2 \mathrm{~b}$ & $44.2 b$ & $69.5 c$ & $2.7 \mathrm{a}$ & $3.2 \mathrm{a}$ & $4.4 \mathrm{a}$ & $1.6 a$ \\
\hline UM1 & $1.2 \mathrm{~b}$ & $37.2 \mathrm{~d}$ & 87.5a & $2.8 \mathrm{a}$ & $2.9 \mathrm{a}$ & 3.2ab & $0.9 b$ \\
\hline UH2 & $1.1 \mathrm{~b}$ & 46.3a & $84.0 \mathrm{~b}$ & 3.3a & $2.7 \mathrm{a}$ & $2.4 \mathrm{~b}$ & $1.4 \mathrm{ab}$ \\
\hline Mean & 1.2 & 41.5 & 81.9 & 2.8 & 2.9 & 3.1 & 1.2 \\
\hline LSD & 0.15 & 0.6 & 1.0 & 0.9 & 0.7 & 1.1 & 0.5 \\
\hline C.V (\%) & 6.2 & 0.7 & 0.6 & 92.3 & 71.4 & 103.6 & 122.3 \\
\hline
\end{tabular}

Means in the same column followed by the same letter are not significantly different at $\mathrm{P} \leq 0.05$, LH2=Lower Highland Zone II, UM1=Upper Midland Zone I, UH2=Upper Highland Zone II, UH3=Upper Highland Zone III, LSD= Least Significant Difference at 5\%, CV (\%)= Coefficient of Variation 
There were significant differences among farm saved seed samples in infection with seedborne fungal pathogens in the four agro-ecological zones. All the farm saved seed samples were infected with Fusarium coeruleum which was the most prevalent pathogen and was significantly different unlike Fusarium solani the least. Within the agro-ecological zones, there were significant differences in infection with all fungal pathogens in LH2, UH2 and UH3 unlike in UM1 where only $F$. coeruleum significantly different. Fusarium coeruleum was the most prevalent pathogen across the four sites with at least 93.3\% of the samples infected. Aspergillus niger was the least fungal pathogen found to infect farm saved tubers in LH2 and UM1 unlike Fusarium sambunicum in UH2 and Fusarium solani in UH3. Highest prevalence with fungal pathogens was in UH2 and UH3 (Table 10).

Table 10. Percentage of farm saved seed potato samples infected various fungal pathogens in different agro-ecological zones in Kikuyu and Nyandarua Counties

\begin{tabular}{|c|c|c|c|c|c|}
\hline \multirow{2}{*}{$\begin{array}{l}\mathrm{N}=79 \\
\text { Pathogen }\end{array}$} & \multicolumn{2}{|c|}{ Kikuyu (n=31) } & \multicolumn{2}{|c|}{ Nyandarua $(\mathrm{n}=48)$} & \multirow[t]{2}{*}{ Mean } \\
\hline & LH2 & UM1 & UH2 & UH3 & \\
\hline Fusarium coeruleum & 93.3a & $100.0 \mathrm{a}$ & $100 \mathrm{a}$ & $100.0 \mathrm{a}$ & $98.3 \mathrm{a}$ \\
\hline Fusarium sambunicum & $67.0 \mathrm{~b}$ & $50.0 \mathrm{~b}$ & $37.5 \mathrm{e}$ & $67.0 \mathrm{c}$ & $55.3 \mathrm{~b}$ \\
\hline Fusarium solani & $37.5 \mathrm{~d}$ & $43.8 \mathrm{~b}$ & $40.1 \mathrm{~d}$ & $12.5 \mathrm{e}$ & $33.5 \mathrm{~d}$ \\
\hline Rhizoctonia solani & $60.0 \mathrm{c}$ & $37.3 \mathrm{~b}$ & $51.0 \mathrm{c}$ & $41.6 \mathrm{~d}$ & $51.4 \mathrm{c}$ \\
\hline Aspergillus niger & $33.2 \mathrm{e}$ & $31.2 \mathrm{~b}$ & $58.3 \mathrm{~b}$ & $70.0 \mathrm{~b}$ & $48.3 c$ \\
\hline Mean & 58.2 & 52.5 & 57.3 & 58.3 & 56.6 \\
\hline LSD & 1.0 & 23.3 & 1.2 & 1.0 & 2.1 \\
\hline CV(\%) & 0.9 & 23.6 & 1.2 & 1.0 & 5.8 \\
\hline
\end{tabular}

Means in the same column followed by the same letter are not significantly different at $\mathrm{P} \leq 0.05, \mathrm{~N}=$ Population, $\mathrm{n}=$ Sample size, LH2=Lower Highland Zone II, UM1=Upper Midland Zone I, UH2=Upper Highland Zone II, UH3=Upper Highland Zone III, LSD= Least Significant Difference at 5\%, CV (\%)= Coefficient of Variation

Table 11. Percentage of farm saved seed potato samples infected with potato viruses in Kikuyu and Nyandarua Counties

\begin{tabular}{|c|c|c|c|c|c|}
\hline \multirow[t]{2}{*}{$\mathrm{N}=79$} & \multicolumn{2}{|c|}{ Kikuyu (n=31) } & \multicolumn{2}{|c|}{ Nyandarua $(\mathrm{n}=48)$} & \multirow[t]{2}{*}{ Mean } \\
\hline & LH2 & UM1 & UH2 & UH3 & \\
\hline PLRV & $0.0 \mathrm{~b}$ & $6.3 \mathrm{~b}$ & $8.3 c$ & $0.0 \mathrm{c}$ & $3.6 \mathrm{c}$ \\
\hline PVA* & $0.0 \mathrm{~b}$ & $0.0 \mathrm{c}$ & $0.0 \mathrm{~d}$ & $0.0 \mathrm{c}$ & $0.0 \mathrm{e}$ \\
\hline PVM* & $0.0 \mathrm{~b}$ & $0.0 \mathrm{c}$ & $0.0 \mathrm{~d}$ & $0.0 \mathrm{c}$ & $0.0 \mathrm{e}$ \\
\hline PVS & $40.0 \mathrm{a}$ & 20.8a & $46.0 \mathrm{a}$ & $54.2 \mathrm{a}$ & $40.2 \mathrm{a}$ \\
\hline PVX & $0.0 \mathrm{~b}$ & $6.2 \mathrm{~b}$ & $12.5 \mathrm{~b}$ & $0.0 \mathrm{c}$ & $4.6 b$ \\
\hline PVY & $0.0 \mathrm{~b}$ & $0.0 \mathrm{c}$ & $0.0 \mathrm{~d}$ & $4.1 \mathrm{~b}$ & $1.0 \mathrm{~d}$ \\
\hline Mean & 6.8 & 5.5 & 11.1 & 9.7 & 8.3 \\
\hline LSD & 0.7 & 0.13 & 0.7 & 0.11 & 0.19 \\
\hline CV (\%) & 6.0 & 1.4 & 3.8 & 0.7 & 13.0 \\
\hline
\end{tabular}

$\mathrm{N}=$ Population, $\mathrm{n}=$ Sample size, LH2=Upper Highland Zone II, UM1 = Upper Midland Zone I, UH2=Upper Highland Zone II, UH3 = Upper Highland Zone III, PLRV=Potato Leaf Roll Virus, PVA = Potato Virus A, PVM = Potato Virus M, PVS= Potato Virus S, PVY= Potato Virus Y, $\mathrm{PVX}=$ Potato Virus $\mathrm{X}$. ${ }^{*}$ Concentrations of PVA and PVM were below the threshold levels of positive controls hence no samples were tested positive for these viruses

There was a significant variation in the mean samples infected with potato viruses and PVS was the post prevalent with up to an average of $40.2 \%$ of the samples were infected. Potato Virus A (PVA) and PVM were not found to infect farm saved seed potato tubers after DAS-ELISA detection. Within the agro-ecological zones, PVS was still the most infectious and significantly different in all the AEZs. In UM1, both PLRV and PVX were not significantly different unlike in UH2 where there were significant differences in the viruses detected with PVS being the most prevalent compared PVX. In UH3, PVS and PVY were significantly different and they were the only viruses detected. There was higher virus infection in samples obtained from Nyandarua compared to Kikuyu (Table 11).

\section{Discussion}

\subsection{Seed potato production practices by small-scale farmers}

The results showed that majority of the farmers had been in potato production for over three years. There is increased profitability of potato since the crop can be grown all year unlike maize which takes up to ten months to mature with only one crop per year in high potential areas. In addition, the sampled agro-ecological zones have low temperatures limiting growth of cereals such as maize hence potato is a dominant crop in these areas due to favorable climate [22]. Some farmers had been involved in potato production for a short duration suggesting diversification of crops from subsistence to market based farming as they increasingly took up production of the crop [10,32]. Studies by [4] revealed high profits accrued from potato production for those farmers who have access to certified seed potato and shifted potato production from subsistence to agribusiness. Longer duration of involvement in potato production could be attributed to higher yields of potato compared to cereals in a limited land area in these agro-ecologies [8]. There has been increasing expansion in land area under potato production in Kenya over the years due to increased profitability of the crop for food security $[8,9]$.

Potato varieties grown included those officially released such as Tigoni and Kenya Mpya and local landraces. Studies by [9] revealed growth of mixed potato varieties by farmers mainly Tigoni and local landraces in Kenya and Uganda. In addition, there has been reported increased uptake of improved potato varieties from public research institutions and NGOs mainly International Potato Center by farmers in Africa [33]. Studies by [8] also revealed increased cultivation of Kenya Karibu, Dutch Robjin and Tigoni potato varieties in Kenya as reported in this study. Shangi was the main variety grown due to its reported acceptability with farmers before official release since National Performance Trials (NPT) are carried out in farmers' fields who access the materials before official release. Some of quality attributes used by farmers in variety selection include marketability, maturity and disease resistance [6]. Recent research has focused on disease resistance and performance of varieties under climate change as opposed to marketability and cooking quality hence farmer preferences may not be met by officially released varieties. Apart from subsistence farming of potato, the ware potato industry in Kenya is also for the fast food industry and the variety Shangi has good peeling, frying and non crumbling quality when processed into fries hence the variety is highly sought by brokers who link farmers with the market. Local landraces were grown for germplasm conservation [9,10]. In 
addition, [33] reported that due to the need to conserve traditional germplasm, few farmers took newly released and improved potato varieties and continued with local landraces hence this could explain use of traditional varieties by some farmers in this study.

Results in this study showed that most farmers renewed seed after four to six cropping seasons while some did not renew seed at all. These results are concurrent with findings of [33] and [5] both reported that most potato farmers in Eastern Africa renewed seed potato after six to eight seasons. Findings of [5] showed that over 74\%, 59\% and $56 \%$ of farmers in Kenya, Uganda and Ethiopia respectively did not renew seed potato until after six seasons. However, these results are contrary to [9] who reported that only $41 \%$ of farmers in Kenya and $25 \%$ in Uganda renewed seed potato unlike $83.9 \%$ reported in this study. Periodic renewal of seed potato by farmers from informal sources mainly neighbours and local markets have been also reported in previous studies $[6,10]$. Due to ease of access, most farmers in Kenya use informal channels in seed renewal and with limited availability of certified seed, few farmers in Kenya renew seed [18]. Growth of local landraces for over 35 years without clean up for diseases also suggests no seed renewal by farmers [9]. Due to reasons such as limited supply of certified seed potato, high certified seed prices and challenges in large scale multiplication of certified seed potato which limits supply, farmers resort to recycling seed from the previous harvest across seasons [5,9]. Recycled seed tubers are highly contaminated with seed borne diseases such as bacterial wilt, potato late blight and Fusarium dry that can lead to total yield loss. Seed renewal is important since continuous use of same seed leads to accumulation of seed borne diseases causing persistent disease outbreaks and low yields [11,34].

Multiple channels were used in acquiring seed potato including both informal and formal seed supply systems. The informal system was the main channel used which included own farm saved seed, local markets and neighbours. All the farmers used own farm saved seed tubers while few accessed certified seed potato from research institutions. These results corresponds to the findings by $[4,5]$ who reported that the informal seed system is the main means of seed acquisition in Eastern Africa and over $98 \%$ of the farmers used seed potato either from either own fields, neighbours and local markets. In addition, [18] and [35] reported that less than $5 \%$ of farmers in Eastern Africa used certified seed potato. Reasons for low usage of certified seed were attributed to inadequate and poor supply, high certified seed prices, inadequate availability of varieties preferred by farmers and lack of knowledge on importance of use of quality seed potato $[9,35]$. The bulkiness of seed potato being vegetatively propagated and centralized production are among key factors limiting adequate seed supply in Kenya forcing farmers to use informal seed supply means [36]. Limited supply of certified seed potato forces farmers to use informal means in seed acquisition which supplies seed tubers that are of poor quality with high prevalence of seed borne diseases hence low yields [4].

All farmers practiced seed selection and freeness from diseases, size of tubers and the sprouting capacity were the quality preferences. Similar observations were made by
[13] by reporting that the main concern for farmers in developing countries is supply of quality seed potato that is free from seed borne diseases especially bacterial wilt (Ralstonia solanacearum) and potato late blight (Phytophthora infestans). However, [9] reported that most farmers in Kenya and Uganda considered yielding ability in variety and seed selection followed by disease resistance. Preference for healthy seed tubers by most farmers was probably because major potato diseases are seed borne attacking the crop in the field and also cause high seed losses during storage [3,4]. In addition, [37] reported that late blight pathogen causes tuber blight, a major storage disease whose inocula remains viable both in storage and in soil hence difficult to control [3]. Farmers use visual selection at harvest and may select latently infected seed potato tubers. Potato production in Kenya is for the ware market and unmarketable (small and chatts) tubers are used as seed hence seed tuber size was reported as a quality trait in this study [38].

Farmers used unspecialized storage methods like jute bags, polythene, heaps, field pits, dark and farm stores while few used diffused light stores leading to high storage losses. Studies by [5] and [9] revealed that most farmers in East Africa stored own seed potato at farm level and did not use recommended storage structures such as diffused light storage and cold stores. In addition, [6] reported that only $5 \%$ of farmers in North Western Ethiopia used diffused light stores and storage structures affected seed tuber quality and its storability. Dark and lit spaces in the houses, delayed harvest and field pits are among the alternative methods of seed potato storage reported in Eastern Africa [5]. Use of poor storage structures leads to high seed losses and disease spread in storage resulting from poor storage conditions and improper post-harvest handling practices [39,40,41,42]. In addition, poor seed tuber storage leads to deterioration in quality and quality of the seed due to attack by diseases mainly Fusarium dry rot [42]. Sub-optimal storage environment especially low relative humidity and high temperature leads to increased respiration and transpiration with subsequent loss in food reserves and water respectively. This leads to reduced tuber weight which reduces vigour by depletion of stored food reserves causing poor crop establishment [40].

Most farmers stored potato for two and three months and few stored for one and four months. These results are contrary to [5] who reported that many farmers in Kenya stored seed potato for one to two months unlike three to four months in Uganda and up to six months storage period in Ethiopia. However, [9] reported that many farmers in Kenya stored seed potato for two months unlike three months in Uganda. Short storage period in Kenya is possibly due to potato being a high value crop, shorter storage durations are used allowing production all year round. Shangi was the commonest variety grown and has a short dormancy period lasting one month hence short storage period [43]. A shorter storage period of three weeks in central Kenya for immediate planting has also been reported [9]. Duration of storage is important since shorter storage necessitates artificial breakage of dormancy while longer seed storage periods increases the physiological age of tubers reducing vigour in addition to predisposing the seed to pest and disease attack especially in poor storage structures $[6,15]$. 
Pests were the main storage constraint but additional problems faced during seed potato storage included rotting of seed potato tubers, poor sprouting and weight loss. This is in agreement with [15] and [19] who reported potato tuber moth and seed rot as major storage problems in Ethiopia and Uganda respectively arising from use of non-specialized storage structures. In addition, [5] also reported poor sprouting in seed potato stored under poor storage conditions leading to production of poor and elongated sprouts since the type of storage structures have significant effects on sprouting [44]. Use of poor storage structures was the main factor causing storage problems resulting from poor storage hygiene, tuber damage and poor post-harvest handling practices [15,39]. Up to $30 \%$ seed damage has been reported in poor structures [41]. Weight loss was reported due to deformation of tubers involving loss in dry matter through respiration and water loss through transpiration which are normal physiological processes affected by the storage environment [40].

The study revealed cutworms as the most damaging pest followed potato tuber moth. Cutworms and rodents were the major field pest while potato tuber moth was the main storage pest. Similar findings were reported by [19] revealing insect pests as the second most important problem after diseases in seed potato storage. However, [45] reported that potato tuber moth to be the most lethal pest unlike cutworms as reported in this study. In addition, [46] reported potato aphids as the most lethal field pests especially in the spread of viral diseases. Cutworms were the most damaging field pest since they cause damage at planting leading to poor field establishment [19]. Pest attack leads to poor crop emergence and low plant stand count thus lowering yields [19]. Storage pests such as potato tuber moth can lead to reduction in marketability of the harvested produce, seed and yield losses [15,45].

Potato diseases namely bacterial wilt (Ralstonia solanacearum) and potato late blight (Phytopthora infestans) were reported to affect potato production. Occurrence of late blight was higher compared to that of bacterial wilt. Studies by [9] and [10] revealed bacterial wilt as the major disease leading to yield reduction in all potato growing areas in Kenya. In addition, [35] and [38] reported bacterial wilt and potato late blight occurrence to be over $70 \%$ and $67 \%$ respectively in Kenyan farms leading to high yield losses. In addition, [5] reported a comparatively lower (74\%) prevalence of bacterial wilt in Kenya than reported on this study. However, [3] reported late blight to be the most damaging potato disease in Kenya. High prevalence of these two diseases could be due to use of poor quality seed tubers from informal seed systems with high infection levels with seed borne diseases [6, 47]. High prevalence of bacterial wilt disease across the four study sites can be attributed to poor farming practices and use of contaminated farm saved seed. Studies by [47] attributed the spread of bacterial wilt to be due to continuous monocropping, contaminated runoff water and tools which are all common practices among small scale-farmers potato farmers in Kenya. Increased prevalence of late blight is due to use of infected seed tubers from informal sources and the disease can cause total yield loss [3].

\subsection{Physical Quality and Infection with Tuber-borne Disease Pathogens}

The study showed no significant differences in the sizes of seed potato tubers used by farmers, which did not meet the minimum physical quality standards for seed size [24]. Majority of the farmers were using chatts and small tubers as seed as opposed to recommended medium sized tubers. Seed potato standards from $[24,48]$ do not classify chatts and small tubers as seed but they are used by farmers who select poor and unmarketable tubers from the crop at harvest and convert it to seed after storage [8]. Similar findings were reported by $[9,18]$ who revealed use of chatts as seed tubers by farmers in East Africa due to limited supply of certified seed. Chatts have low weight with poor vigour due to low food reserves since the recommended weight of (medium) tubers ideal for seed is 40-70g [49]. In addition, chatts have high virus infection levels and leads to production of small and misshaped tubers of low marketability $[18,34]$. The sprout length met the recommended length but the weights $(<40 \mathrm{~g})$ were below the recommended standard weight range (40-70g) for seed potato tubers [49]. High sprout length could be due to sprout initiation mechanisms used by farmers such as partial exposure to light, use of field pits lined with straw or grass and seed treatments [9,39]. Previous studies have shown significant effect of postharvest handling practices on sprouting of seed tubers eventually affecting the quality of seed hence use of poor storage structures lowers quality of stored seed tubers [44].

The study revealed no significant difference in the weights of seed tubers between the agro-ecological zones because most farmers were using the same size of the seed tubers. Studies by [11] revealed seed higher cases of seed degeneration in areas where chatts and small tubers were used as seed. Use of chatts and small tubers explains the low seed weight or could be due to water and dry matter loss from tubers due transpiration and respiration respectively which is high in poor storage structures [40]. Seed tubers of low weight and poor sprouts have low vigour and poor crop emergence leading to reduced yields $[49,50]$.

Results showed significantly high infection levels with bacterial wilt in all the agro-ecological. These results correspond with [50] who reported $80.7 \%$ occurrence of the disease Ethiopia by testing symptomatic samples. In addition, [51] reported up to 99\% occurrence of bacterial wilt in Kenya through a survey. In contrast, [5] reported $74 \%$ bacterial wilt incidence in Kenya. In addition, [47] reported $70 \%$ incidence of bacterial wilt in Kenya causing over $50 \%$ yield loss. Use of seed potato from informal supply systems has proliferated spread of the disease. The $R$. solanacearum inocula is spread through infected soil, volunteer crops, infected seed tubers, runoff water and tools [10]. Studies by [18] revealed high prevalence of brown rot in Eastern Africa to be due to use of seed potato from informal supply such as farm saved as shown in this study. Tubers infected with bacterial wilt have poor crop performance leading high losses [42,53].

There were no significant differences among the agoecological zones on infection with fungal pathogens. Multiple seed borne fungal pathogens were found to infect 
farm saved seed potato and Fusarium coeruleum was the most dominant. These findings correspond with [54] who reported Fusarium coeruleum as the commonest Fusarium dry rot pathogen in potato. In addition, [55] reported higher cases of tuber rot due to Aspergillus niger attack in sweet potato tubers in Nigeria. However, [56] reported lower infection levels with Fusarium sambunicum isolated from stored seed potato. In addition, [57] reported a higher incidence of Rhizoctonia solani with up to $80 \%$ prevalence in Pakistan unlike 51.2\% revealed in this study. Studies by [58] showed F. sambunicum as the most aggressive dry rot causing pathogen unlike Fusarium coeruleum reported this study. Fusarium dry rot was highly prevalent in farm saved tubers because the disease is seed borne and it's proliferated by poor post harvest handling practices. Dry rot causing pathogens including $F$. coeruleum, $F$. sambunicum and $F$.solani are all seed borne and infect healthy tubers through wounds at harvest [59]. A high infection level with black scurf was due to the pathogen being seed and soil borne. Highly viable seed and soil borne inocula of Rhizoctonia solani are carried in the soil or in infected tubers leading to spread of the disease $[17,60,61]$. Seed tubers infected with dry rot, black scurf and other fungal pathogens causes high storage losses through rotting and reduction in marketability of the ware potato due to formation of blemishes on skin of tubers [26,59,62].

Potato Virus S (PVS) was the most dominant virus infecting farm saved seed tubers. Both Potato Virus A (PVA) and Potato Virus M (PVM) tested negative. The proportion of samples infected with Potato Leaf Roll Virus (PLRV), Potato Virus X (PVX) and Potato Virus Y (PVY) were comparatively low. These results corresponds to [51] who reported high occurrence of Potato Virus $S$ (80.1\%) in Ethiopia and no positive samples for PVA were detected the study. However, [5] reported higher virus infection levels in East Africa. In addition, [63] working on screening of viruses for seed certification, reported higher occurrence of PVY and PVA unlike the results in this study. Higher occurrence of PVY was also reported in studies conducted in Tunisia [64]. Infection with viruses could be due to use of infected seed tubers from informal supply channels especially small tubers that have high viral loads [6,34]. Continuous use of the same seed potato without renewal leads to accumulation of seed borne pathogens including viruses [11]. Potato viruses are of phytosanitary importance in seed potato certification scheme and trade. Presence of viruses in seed tubers leads to production of smaller tubers and eventually yields loss [34,65]. Absence of PVA and PVM in farm saved seed tubers after detection using DAS-ELISA is not conclusive enough to ascertain that the samples were free from these two viruses. Studies have suggested use of molecular techniques such as Polymerase Chain Reaction (PCR) alongside DAS-ELISA so as to detect viruses even under low concentrations [66].

\section{Conclusions and Recommendations}

Most farmers rarely use certified seed and the informal seed system is the main channel for acquiring seed tubers. All famers use farm saved seed potato tubers and most store seed for two or three months in poor storage structures. Disease freeness is the main seed quality preference but farmers use tuber size in seed selection from the produce at harvest. Pests are a challenge in the field and also during storage leading to high losses. Farm saved seed potato is of poor health status with multiple infections with seed borne diseases. Farmers should be sensitized on use of recommended post-harvest handling practices to reduce seed losses. There should be increased supply of certified seed potato. Farmers should therefore be enlightened on the importance of use of certified seed potato for optimal potato production.

\section{Acknowledgements}

This publication was made possible through support provided by Alliance for a Green Revolution in Africa (AGRA). Opinions expressed herein are those of author(s) and do not necessarily reflect the views of AGRA.

\section{Statement of Competing Interests}

The authors do not have any competing interests.

\section{References}

[1] Wang'ombe, J.G., and van Dijk, M.P., Low potato yields in Kenya: Do conventional input innovations account for the yields disparity? International Journal of Agricultural Marketing, 2(2). 034-45. 2015.

[2] Muthoni, J., Nyamongo, D., and Mbiyu, M.., Climatic change, its likely impact on potato (Solanum tuberosum L.) production in Kenya and plausible coping measures, International Journal of Horticulture, 7. 115-123. 2017.

[3] Mariita, M.O., Nyangeri, J., and Makatiani, J.K., Assessing the incidences of late blight disease on Irish potato varieties in Kisii County, Kenya. Annual Research and Review in Biology, 9(6). 18. 2016.

[4] Okello, J., Zhou, Y., Kwikiriza, N., Ogut, S., Barker, I., Shulte Geldermann, E., Atieno, E., and Ahmed, T.J Productivity and food security effects of using certified seed potato: The case of Kenya's potato farmers, Agriculture and Food Security, 6(25). 2-9. 2017.

[5] Gildemacher, R. P., Demo, P., Baker, I., Kaguongo, W., and Wakahiu, M., A description of potato seed systems in Kenya, Uganda and Ethiopia. American Journal of Potato Research, 86. 372-382. 2009.

[6] Hirpa, A., Miranda, P., Agajie, T., Lommen, M., Lansik,A., Struik, C.P., and Tsegaye, A., Analysis of seed potato systems in Ethiopia, American Potato Research Journal, 87. 537-522. 2010.

[7] Kaguongo, W., Maingi, G., Barker, I., Nganga, N., and Guenthner, J., The value of seed potatoes from four systems in Kenya, American Journal of Potato Research., 91(1). 109-118. 2013.

[8] Muthoni, J., Kabira, J., Kipkoech, D., Abong, G., and Nderitu, J. $\mathrm{H}$., Yield performance of potato seed tubers after storage in a diffused light store, Journal of Agricultural Sciences, 6. 21-28. 2013.

[9] Kaguongo, W., Gildermacher, R.P., Demo, P., Wagoire, W., Kinyae, P., Andrade, J., Forbes, G., Fuglie K., and Thiele, G., Farmer practices and adoption of improved potato varieties in Kenya. Kenya Agricultural Research Institute (KARI), Nairobi Kenya. 2008.

[10] Muthoni, J., and Nyamongo, D., A review of constraints to ware and Irish potato production in Kenya, Journal of Horticulture and Forestry, 7. 098-102. 2009.

[11] Thomas-Sharma, S., Abdulrahman, A., Ali, S., Andre Piedra, L. J., Bao, S., Charkowski, A.O., Crook, D., Kadian, M.K.M., Kromann, P., Struik, C.P., L. Torrence, L., Garett, K. A., and Forbes, G.A., 
Seed degeneration in potato: The need for an integrated seed health strategy to mitigate the problem in developing countries, Plant Pathology Journal, 65(1). 3-16. 2015.

[12] Waswa, M., Kakuhenzire, R., and Ochwo-Ssemakula, M., Effect of thermotherapy duration, virus type and cultivar interactions on elimination of potato viruses $\mathrm{X}$ and $\mathrm{S}$ in infected seed stocks, African Journal of Plant Science, 11(3). 61-70. 2017.

[13] Fuglie, K., Priorities for potato research in developing countries: Results from a survey, American Journal of Potato Research, 84. 353-365. 2007

[14] Center for Agricultural and Rural Cooperation (CTA), Seed systems, science and policy in East and Central Africa. CTA, Wageningen, The Netherlands. 2014.

[15] Mulatu, E., Ibrahim, O., and Bekele, D., Improving potato seed tuber quality and producer's livelihoods in Haraghe, Eastern Ethiopia, Journal of New Seeds, 7(3). 31-56. 2005.

[16] Bus, C. B., and Wustman, R., The Canon of potato Science: Seed tubers, Potato Research, 50. 319-322. 2007.

[17] Fiers, M., Edel-Hermann, V., Haraud, C., Gautheron, N., Chatot, C., LeHingrat, Y., Bouchek-Mechiche, K., and Steiberg, C., Genetic diversity of Rhizoctonia solani associated with potato tubers in France, Mycologia, 103(6). 1230-1244. 2011.

[18] Gildemacher, R.P., Schulte-Geldermann, E., Borus, D., Demo, P., Kinyae, P., Mundia, P., and Struik, C. P., Seed potato quality improvement through positive selection by smallholder farmers in Kenya, Potato Research Journal, 54. 253-266. 2011.

[19] Okonya, J., and Kroschel, J., Farmers' knowledge and perceptions of potato pests and their management in Uganda. Journal of Agriculture and Rural Development in Tropics and Sub Tropics, 117(1). 87-97. 2016.

[20] Shulte - Geldermann, E., Gildemacher, R.P., and Struik, C. P., Improving seed health and seed performance by positive selection in three Kenyan potato varieties., Potato Research, 89. 429-437. 2012.

[21] Ayalew, T., Analysis of seed potato systems with special focus to Ethiopia: Review, Asian Journal of Agricultural Research, 83. 122-135. 2014.

[22] Jaetzold, R., Schmidt, H., Hornet, B., and Shisanya, C., Farm management handbook of Kenya-Natural conditions and farm management information. Second Edition Volume II (Central Kenya).Ministry of Agriculture/GTZ, Nairobi Kenya. 2007.

[23] Leech, N.L., Barret, K.C., and Morgan, G.A., SPSS for intermediate statistics: Use and Interpretation. Psychology Press. 2005.

[24] United Nations Economic Commission for Europe (UNECE). Standards for marketing and commercial quality control of seed potatoes, United Nations (UN), Geneva Switzerland. 2006.

[25] Food and Agriculture Organization of the United Nations (FAO)., Quality declared planting material: Standards and protocols of vegetatively propagated crops. Plant Protection Paper, Rome Italy. 2014.

[26] Fiers, M., Albovouette, C., Hingrat, Y., and Steinberg, C., Diversity of microorganisms associated with superficial blemishes of potato tubers and pathogenicity assessment, European Journal of Plant Pathology, 128. 353-371. 2007.

[27] Das, S., Shah, F. A., Butler, R. C., Fallon, R., Stewart, A., Raikar, S., and Pitman, A. R., Genetic variability and pathogenicity of Rhizoctonia solani associated with black scurf of potato in New Zealand, Plant Pathology , 63(3).651-666. 2013.

[28] Priou, S., Laboratory manual for Nitrocellulose Membrane Enzyme Linked Immunosorbent Assay (NCM ELSA) kit for detection of Ralstonia solanacearum in potato, International Potato Center (CIP), Lima, Peru. 2001.

[29] Clark, M. F., and Adams, A. N., Characteristics of microplate method of Enzyme Linked Immunosorbent Assay (ELISA) for detection of plant viruses, Journal of General Virology, 34. 475-483. 1977.

[30] Priou, S., Laboratory manual for Double Antibody Sandwich Enzyme Linked Immunosorbent Assay (DAS-ELISA) kit for detection of potato viruses. International Potato Center, Lima Peru. 2001.

[31] Payne, R. W., Murray, D. A., Harding, S. A., Baird, D. B., and Soutar, D. M., Introduction to GenStat for Windows (10th Edition), VSN International, Hemel Hempstead. United Kingdom. 2007.

[32] Janssens, S., Wiersema, G., Goos, H., and Wiersma, W., The value chain of seed and ware potatoes in Kenya: Opportunities for Improvement. International Potato Center (CIP), Lima Peru. 2013.
[33] Nigusse, Z., Alemayehu, G., Adgo, E., and Freyer, B., Reasons for acceptance of improved potato varieties by smallholder producers, International Journal of Vegetable Science, 22(4). 346-352. 2016.

[34] Njukeng, P., Chewachong, G., Sakwe, P., Chofong, G., Nkeabeng, L., Demo, P., and Njualem, K., Prevalence of six viruses in potato seed tubers produced in informal seed system in the North West Region of Cameroon, Cameroon Journal of Experimental Biology, 9(1). 44-49. 2013

[35] Muthoni, J., Mbiyu, W., and Nyamongo, D., A review of potato seed systems and germplasm conservation in Kenya, Journal of Agricultural and Food Information, 11. 157-167. 2010.

[36] Demo,P., Lemaga, L., Kakuhenzire, R., Shultz, S., Borus, D., Baker, I., Woldegiorgis, G., Parker, G., and Shulte-Geldermann, E., Strategies to improve seed potato quality and supply in SubSaharan Africa: Experience from interventions in five countries. CABI International. Potato and sweet potato in Africa: Transforming the Value Chains for Food and Nutrition Security (eds J. Low et al.). 2015.

[37] Wiik, L., Potato late blight and tuber yield: Results from 30 years of field trials, Potato Research 57(1). 77-98. 2014.

[38] Muthoni, J., Shimelis, H., and Melis, R., Potato production in Kenya: Farming systems and production constraints, Journal of Agricultural Science 5. 5182-5197. 2009.

[39] Shibairo, I. S., Demo, P., Kabira, J., Gildermacher, R.P., Gachango, E., Narla, D.R., and Menza, K., Effects of Gibberellic Acid (GA3) on sprouting and quality of potato seed tubers in diffused light and pit storage. Journal of Biological Sciences 6: 723-733. 2006.

[40] Wustman, R., and Struik, C. P., The canon of potato science: Seed and ware potato storage, Potato Research 50. 351-355.2007.

[41] Endale, G., Gebremedhin, W., Bekele, K., and Lemaga, B., Postharvest management In root and tuber crops: The untapped resources, ed. W. Gebremedhin, G. Endale, and B. Lemaga. Ethiopian Institute of Agricultural Research, Addis Ababa Ethiopia. 2008.

[42] Wustman, R., The Canon of potato science: Storage diseases and pests, Potato Research, 50. 289-292.2007.

[43] National Potato Council of Kenya (NPCK), National Potato Variety Catalogue, Nairobi Kenya.http://npck.org/. Date accessed: 15/6/2016. 2016.

[44] Oliveira, J. S., Moot, D., Brown, E. H., Gash, A., and Sinton, S. Sprout development of seed potato tuber after different storage conditions. Agronomy New Zealand, 42. 53-58. 2012.

[45] Van der Waal, J. E., Steyn, J.M., Franke, A. C., and Haverkort, A. J., Grower perceptions of biotic and abiotic risks of potato production in South Africa, Crop Protection, 84. 44-55.2016.

[46] Were, H., Kabira, J., Olubayo, F., Karinga, J., Aura, J., Lees, A., Cowan, G., and Torrance, L., Occurrence and distribution of potato pests and diseases in Kenya, Potato Research,56(4). 325342. 2013.

[47] Muthoni, J., Kabira, J., Shimelis, H., and Melis, R., Spread of bacterial wilt disease of potatoes in Kenya: Who is to blame? International Journal of Horticulture, 4.10-15.2014.

[48] Common Market for Eastern and Central Africa (COMESA)., COMESA seed trade harmonization regulations. Alliance for Commodity Trade in Eastern and Southern Africa (ACTESA), Lusaka Zambia.2016.

[49] Fujardo, J., Quality declared planting materials: Protocols and Standards for vegetatively propagated crops. Food and Agriculture Organization (FAO) of United Nations, Rome Italy.2010.

[50] Bakht, A., Yaqub, A., Ali, M., Ullah, M., Khan, A., Muhammad, T., Khan, A., and Aya, M., Response of potato genotypes to different levels of nitrogen, Journal of Pure and Applied Biology, 5(3).369-377. 2016.

[51] Bekele, B., Abate, E., Asefa, A., and Dickson, M., Incidence of potato viruses and bacterial wilt disease in the West Amhara SubRegion of Ethiopia., Journal of Plant Pathology, 93. 149-157.2011.

[52] Kwambai, T., Omunyin, M., Okalebo, J., and Gildemacher, P., Assessment of potato bacterial wilt disease status in North Rift Valley of Kenya: A Survey. Innovations as the key to green revolution in Africa, 449-456.2011.

[53] Mwangi, K., Nyende, B., Demo, P., and Matiru, N., Detection of Ralstonia solanacearum in potato (Solanum tuberosum L.) using stems instead of tubers, African Journal of Biotechnology, 7. 1644-1649. 2008.

[54] Heltoft, P., Brierley, J.L., Lees, A. K., Sullivan, L., Lynott, J., and Hermansen, A., The relationship between soil inoculum and the 
development of Fusarium dry rot in potato cultivars Asterix and Saturna, European Journal of Plant Pathology, 146 (3). 711-714. 2016.

[55] Suleiman, M. N., and Falaiye, N.T., .Invitro control of fungus associated with bio-deterioration of sweet potato (Ipomea batatas (L).Lam) tubers, FUTA Journal of Research in Science, 9(1). 1-7. 2014.

[56] Estrada Jr, R., Gutmestad, N.C., Rivera, V.V., and Secor, A.G., Fusarium graminearum as a dry rot pathogen of potato in the USA: Prevalence, comparison of host isolate aggressiveness and factors affecting aetiology, Plant Pathology, 59.1141-1120. 2010

[57] Rauf, C. A., Ashaf, M., and Ahmad, I., Occurrence and distribution of black scurf of potato in Pakistan. Pakistan Journal of Botany, 39.1341-1352.2007.

[58] Ammar, N., Nefzi, A., Jabnoun-Khiareddine, H., and DaamiRemadi, M., Control of Fusarium dry rot incited by Fusarium oxysporum fsp tuberosi using Sargassum vulgare aqueous and organic Extracts, Journal of Microbial and Biochemical Technology, 9. 200-208. 2017.

[59] Irabi, A.I., Abubaker, M.Y, and Elhassan, S. M., Role of infected seed potato tuber in contamination of land and clean potato stocks with common scab, Journal of Advances in Biology and Biotechnology, 12:1-8. 2017.

[60] Rauf, C. A., Naz, F., Ahmad, I., Haque, I. U., and Riaz, A., Management of black scurf of potato with effective microbes (em), biological potassium fertilizer (bpf) and Trichoderma harzianum,
International Journal of Agriculture and Biology, 17(3). 601- 606. 2015.

[61] Brierley, J. L., Hilton, A. J., Wale, S.J., Woodhall, J.W., and Lees, A.K., The relative importance of seed and soil borne inoculums of Rhizoctonia solani AG-3 in causing black scurf of potato, Potato Research, 59(2).181-193.2016.

[62] Wharton, P. S., and W. W. Kirk, W.W., Evaluation of biological seed treatments in combination with management practices for the control of Fusarium dry rot of potato, Biological Control, 73.2330.2014.

[63] Saad, A., Sobhi, H., and Abou-Jawdah, Y., Incidence of potato virus diseases and their significance for a seed certification program in Lebanon, Phytopathologia Mediterranea, 40(2). 113118. 2001.

[64] Djilani-Khouadja, F., Glais, L., Tribodet, M., Kerlan,C., and Fakhfakh,H., Incidence of potato viruses and characterisation of Potato Virus Y variability in late season planted potato crops in Northern Tunisia, European Journal of Plant Pathology, 126 (4). 479-488. 2010.

[65] Rahman, M., and Akanda, M., Effect of Potato Leaf Roll Virus on disease incidence, plant growth and yield parameters of potato, Bangladesh Journal of Agricultural Research, 35. 359-366. 2010.

[66] El-Araby, W. S., Ibrahim, I.A., Hameida, A. A., Mahmoud, A., Soliman, A. M., El-Attar, A. K., and Mazyad, H. M., Biological, serological and molecular diagnosis of three major potato viruses in Egypt. International Journal of Virology, 5 (2). 77-88. 2009. 